University of Nebraska - Lincoln

DigitalCommons@University of Nebraska - Lincoln

\title{
Influence of the Pacific Decadal Oscillation on the climate of the Sierra Nevada, California and Nevada
}

\author{
Larry Benson \\ U.S. Geological Survey, great.basin666@gmail.com \\ Braddock Linsley \\ State University of New York \\ Joe Smoot \\ U.S. Geological Survey \\ Scott Mensing \\ University of Nevada - Reno \\ Steve Lund \\ University of Southern California, slund@usc.edu
}

See next page for additional authors

Follow this and additional works at: https://digitalcommons.unl.edu/usgsstaffpub

Part of the Geology Commons, Oceanography and Atmospheric Sciences and Meteorology Commons, Other Earth Sciences Commons, and the Other Environmental Sciences Commons

Benson, Larry; Linsley, Braddock; Smoot, Joe; Mensing, Scott; Lund, Steve; Stine, Scott; and SarnaWojcicki, Andre, "Influence of the Pacific Decadal Oscillation on the climate of the Sierra Nevada, California and Nevada" (2003). USGS Staff -- Published Research. 782.

https://digitalcommons.unl.edu/usgsstaffpub/782

This Article is brought to you for free and open access by the US Geological Survey at DigitalCommons@University of Nebraska - Lincoln. It has been accepted for inclusion in USGS Staff -- Published Research by an authorized administrator of DigitalCommons@University of Nebraska - Lincoln. 


\section{Authors}

Larry Benson, Braddock Linsley, Joe Smoot, Scott Mensing, Steve Lund, Scott Stine, and Andre SarnaWojcicki 


\title{
Influence of the Pacific Decadal Oscillation on the climate of the Sierra Nevada, California and Nevada
}

\author{
Larry Benson, ${ }^{*, a}$ Braddock Linsley, ${ }^{\mathrm{b}}$ Joe Smoot, ${ }^{\mathrm{c}}$ Scott Mensing, ${ }^{\mathrm{d}}$ Steve Lund, \\ Scott Stine, ${ }^{f}$ and Andre Sarna-Wojcicki ${ }^{\mathrm{g}}$ \\ ${ }^{\text {a }}$ U.S. Geological Survey, 3215 Marine Street, Boulder, CO 80303-1066, USA \\ ${ }^{\mathrm{b}}$ Earth and Atmospheric Sciences, State University of New York, 1400 Washington Avenue, Albany, NY 12222-0001, USA \\ ${ }^{\mathrm{c}}$ U.S. Geological Survey, MS 955, Reston, VA 22090, USA \\ ${ }^{\mathrm{d}}$ Department of Geography, University of Nevada, Reno, NV 89557, USA \\ ${ }^{\mathrm{e}}$ Department of Earth Sciences, University of Southern California, Los Angeles, CA 90089, USA \\ ${ }^{\mathrm{f}}$ California State University, Hayward, CA 94542, USA \\ ${ }^{g}$ U.S. Geological Survey, MS 975, Middlefield Road, Menlo Park, CA 94025, USA
}

Received 4 June 2002

\begin{abstract}
Mono Lake sediments have recorded five major oscillations in the hydrologic balance between A.D. 1700 and 1941 . These oscillations can be correlated with tree-ring-based oscillations in Sierra Nevada snowpack. Comparison of a tree-ring-based reconstruction of the Pacific Decadal Oscillation (PDO) index (D'Arrigo et al., 2001) with a coral-based reconstruction of Subtropical South Pacific sea-surface temperature (Linsley et al., 2000) indicates a high degree of correlation between the two records during the past 300 yr. This suggests that the PDO has been a pan-Pacific phenomena for at least the past few hundred years. Major oscillations in the hydrologic balance of the Sierra Nevada correspond to changes in the sign of the PDO with extreme droughts occurring during PDO maxima. Four droughts centered on A.D. 1710, 1770, 1850, and 1930 indicate PDO-related drought reoccurrence intervals ranging from 60 to $80 \mathrm{yr}$.
\end{abstract}

(C) 2003 Elsevier Science (USA). All rights reserved.

Keywords: PDO; Pacific Decadal Oscillation; Mono Lake; Sierra Nevada

\section{Introduction}

Mono Lake, California, is one of four large lakes that lie along the western margin of the Great Basin (Fig. 1). It is a hydrologically closed lake that receives runoff from five perennial streams (Fig. 2). Since A.D. 1941, two of the largest streams have been diverted for water and power to the city of Los Angeles. As a result, the lake fell $13.7 \mathrm{~m}$, experiencing a $50 \%$ decrease in volume.

Stine (1990) was the first to document large-scale fluctuations in the level of Mono Lake over the late Holocene, combining sedimentary evidence for lake transgression and

* Corresponding author. Fax: +1-303-447-2505.

E-mail address: lbenson@usgs.gov (L. Benson). regression with ${ }^{14} \mathrm{C}$ dates of the remains of vegetation killed during transgressions.

Most core-based studies of Mono Lake Holocene-age sediments have been confined to the shallow-water nearshore environment (e.g., Newton, 1994; Davis, 1999). Rates of sedimentation in the near-shore environment are lower than rates in deep-water environments except near deltaic areas. The near-shore environment is also the site of frequent erosion, reworking, and resuspension of sediment that blur $\delta^{18} \mathrm{O}$, pollen, and other climate records.

In A.D. 1991, Jellison (1996) collected a series of freeze cores (ML91 FC) from the deep (39-m) basin located $\sim 1$ $\mathrm{km}$ south of Paoha Island (Fig. 2). ${ }^{239+240} \mathrm{Pu}$ and ${ }^{210} \mathrm{~Pb}$ determinations on core ML91 FC6 were used to determine a mean sedimentation rate of $7 \mathrm{~mm} \mathrm{yr}^{-1}$ for the upper $65 \mathrm{~cm}$ of sediment. $\mathrm{Li}$ et al. (1997) performed $\delta^{18} \mathrm{O}$ analyses at 
4-mm intervals in core ML91 FC3. They reinterpreted the ${ }^{210} \mathrm{~Pb}$ data from Jellison (1996) to indicate a change in sedimentation rate from $7.5 \mathrm{~mm} \mathrm{yr}^{-1}$ above $35 \mathrm{~cm}$ to $4 \mathrm{~mm}$ $\mathrm{yr}^{-1}$ between 35 and $55 \mathrm{~cm}$. It is, however, not obvious from the data which age model is more accurate. Using their age model and the $\delta^{18} \mathrm{O}$ record from core ML91, Li et al. (1997) concluded that minima in lake level occurred around A.D. 1860, 1900, and 1933. This conclusion was generally consistent with historical observations (Harding, 1965).

In this article, we compare a 300-yr, continuous, highresolution record of change in the hydrologic balance of Mono Lake with two recently published tree-ring-based records of Sierran climate change from the southern and northern Sierra Nevada (Graumlich, 1993; Meko et al., 2001). We show that the three paleoclimatic records share similar features, indicating that five major climate oscillations impacted the entire Sierra Nevada between A.D. $\sim 1700$ and 2000. We also compare the Sierran hydrologicbalance records with a tree-ring-based reconstruction of the PDO index, demonstrating that some extreme Sierran droughts occurred during PDO maxima (D'Arrigo et al., 2001). Finally, we show that a coral-based record of Subtropical South Pacific sea-surface temperature (SST), previously shown to correlate with the instrumental record of the PDO index during the past $100 \mathrm{yr}$ of (Linsley et al., 2000) also correlates well with the reconstructed PDO index (D'Arrigo et al., 2001) over the past $300 \mathrm{yr}$. This suggests that the PDO is a pan-Pacific phenomena which has persisted for at least the past 300 years.

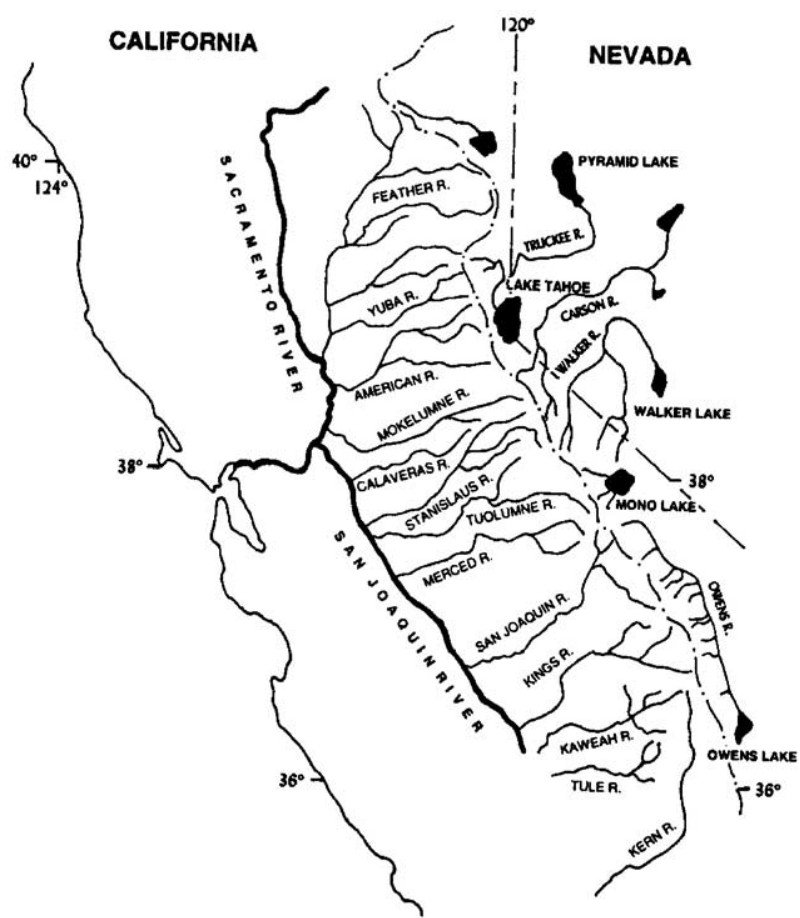

Fig. 1. Sierra Nevada drainage. The Sierra Nevada Divide (western boundary of the Great Basin) is indicated by the dot-dashed line.

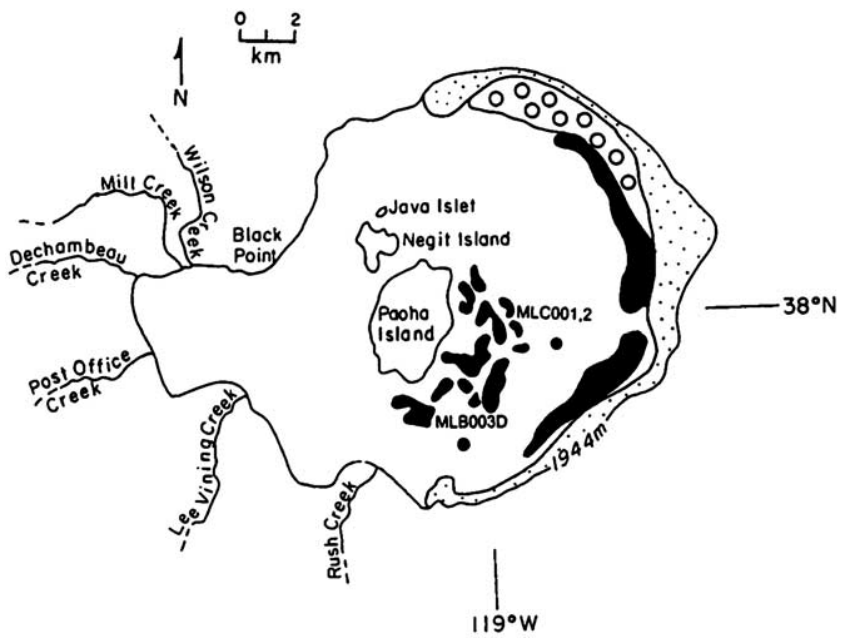

Fig. 2. Location of coring sites (MLB003D and MLC001,2) at Mono Lake, California. Solid black areas indicate sites of disturbed or slumped sediment. Area with open circles indicates location of tufa boulders, and dotted areas indicate sands. Surface sediment data are shown only for the eastern half of the lake.

\section{Methods}

Coring

A bottom-feature map for Mono Lake, created by the Pelagos Corporation ${ }^{1}$ in 1986 for the Los Angeles Department of Water and Power, indicates that a discontinuous 2.5- to 3.0-km-wide band of disturbed soft sediment encircles Paoha Island (Fig. 2). A 1.0- to 1.6-km-wide band of sand borders the eastern shore of the lake and a $0.5-$ to 1.1-km-wide band of slumped sediment lies lakeward of the sands. To avoid areas containing reworked and disturbed surface sediments, two piston cores (MLC001 and MLC002) were taken from the same location in the eastern basin of Mono Lake $\left(37.992^{\circ} \mathrm{N}, 118.975^{\circ} \mathrm{W}\right)$ in $\sim 30 \mathrm{~m}$ of water between areas containing disturbed and slumped surface sediment. A single box core (MLB003) was taken from the southern basin $\left(37.966^{\circ} \mathrm{N}, 118.998^{\circ} \mathrm{W}\right)$ in $\sim 35 \mathrm{~m}$ of water (Fig. 2).

Core MLC001 is $5.39 \mathrm{~m}$ in length and its trigger core (MLC001T) is $0.91 \mathrm{~m}$ in length. $320 \mathrm{~kg}$ of weight was used during recovery of core MLC002 in order to sink the weight stand below the sediment-water interface before the piston was allowed to travel the core barrel. This allowed recovery of sediments from depths greater than $6 \mathrm{~m}$. Core MLC002 is $6.09 \mathrm{~m}$ in length and its trigger core (MLC002T) is $0.93 \mathrm{~m}$ in length. Porosity data from cores MLC001 and MLC002 indicate that the top of core MLC002 was located $2.46 \mathrm{~m}$ below the sediment-water interface (Fig. 3). The box core (MLB003) contained $\sim 80 \mathrm{~cm}$ of sediment and was hand cored four times with polycarbonate tubes $7.5 \mathrm{~cm}$ in

\footnotetext{
${ }^{1}$ Use of product or firm trade names in this report does not imply endorsement by the U.S. Geological Survey.
} 


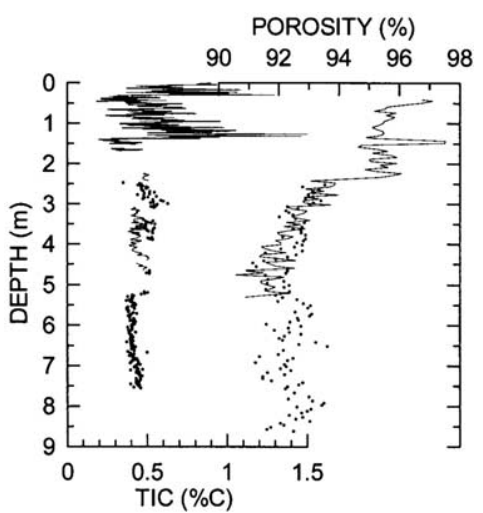

Fig. 3. TIC and porosity data for Mono Lake cores. In the left plot, the thin black lines indicate TIC data for cores MLB003D $(0.0-0.46 \mathrm{~m})$ and MLC001. Small black dots indicate TIC data for MLC002. In the plot on the right, the thin black line indicates porosity data for MLC001 and the small black dots indicate porosity data for MLC002.

diameter. Sediment compression did not occur during hand coring.

Core disturbance, sampling, and analysis

Sedimentological examination of the cores indicated that the upper $25 \mathrm{~cm}$ of core MLC001 was disturbed, and the top $2 \mathrm{~cm}$ of core MLC001T was contorted. The upper $5 \mathrm{~cm}$ of core MLC002 was lost during core recovery, and the top 6 $\mathrm{cm}$ of core MLC002T was disturbed. Sediments in cores MLB003 and MLC001T were finely laminated, as was the top $156 \mathrm{~cm}$ of core MLC001. Below $156 \mathrm{~cm}$ in core MLC001, and throughout the length of MLC002, laminations were infrequent, indistinct, and often contorted and the core was light in color, contrasting with the intense black, red, green, and brown laminations characteristic of the upper $156 \mathrm{~cm}$ of sediment.

The top $60 \mathrm{~cm}$ of core MLC001T, the entire length (79 $\mathrm{cm}$ ) of core MLB003D, and the 39- to 169-cm interval of core MLC001 were sampled continuously at $0.5-\mathrm{cm}$ intervals. Undisturbed sections of core MLC001 between 223 and $446 \mathrm{~cm}$ were sampled at 2-cm intervals, and sections of core MLC002 that appeared undisturbed were sampled at 2 -cm intervals. Wet-dry measurements were made at $\sim 5$-cm intervals throughout the three cores. A density of $2.5 \mathrm{~g} \mathrm{~cm}^{-3}$ was used to calculate porosity.

Samples were washed in deionized water, freeze dried, and homogenized prior to isotopic $\left(\delta^{18} \mathrm{O}\right)$ and coulometric analyses of total inorganic carbon (TIC) and total carbon (TC) (Benson et al., 1996). Total organic carbon (TOC) was determined by difference. The detection limit for TIC was $\sim 0.1 \%$ C. Powdered carbonate material was analyzed using a Micromass Optima gas-source triple-collector mass spectrometer equipped with a dual inlet and interfaced with a MultiPrep automated sample preparation device. The precision of analyses of reference standard NBS-19 is estimated to be $\pm 0.04 \%$ for $\delta^{18} \mathrm{O}$.
$\mathrm{X}$-ray diffraction analyses for aragonite and calcite were carried out every $5 \mathrm{~cm}$ within the top $30 \mathrm{~cm}$ of core MLB003D and between 45 and $170 \mathrm{~cm}$ in core MLC001. Six standards were created using mixtures of calcite and aragonite ranging from $0 \%$ aragonite and $100 \%$ calcite to $0 \%$ calcite and $100 \%$ aragonite. Carbonate samples totaling $0.1 \mathrm{~g}$ were combined with a matrix composed of $0.5 \mathrm{~g}$ smectite and $0.4 \mathrm{~g}$ microcline feldspar and homogenized. The areas of the calcite peak at $29.4^{\circ} 2 \theta$ and the aragonite peak at $33.13^{\circ} 2 \theta(\mathrm{Cu} \mathrm{k} \alpha$ radiation) were used to calculate weight percentages of calcite and aragonite in core samples relative to peak areas of the standards. Because a peak for pyrite $\left(33.08^{\circ} 2 \theta\right)$ overlaps the aragonite peak, the peak area for aragonite was measured before and after acidification with HCL.

Two thin ( $\sim 5-\mathrm{mm}$ thick) white beds at 15.5 and $24.5 \mathrm{~cm}$ in ML001T and at 20 and $28.5 \mathrm{~cm}$ in MLB003D were used to aid in the correlation of the upper parts of the two cores. A series of ${ }^{14} \mathrm{C}$ dates were also obtained on TOC and pollen samples from cores MLB003D, MLC001, and MLC001T (Table 1). Conversions of ${ }^{14} \mathrm{C}$ dates to calibrated years (yr) in this article have been done using tables from Stuiver et al. (1998).

\section{Age control}

Problems with a ${ }^{14}$ C-Based age model

The ${ }^{14} \mathrm{C}$ data indicate that sediments at the base and below the laminated unit of MLC001 are late-Pleistocene in

Table 1

Radiocarbon ages of pollen and the $\mathrm{TOC}^{\mathrm{a}}$ fraction from cores MLB003D, MLC001T, MLC001, and MLC002

\begin{tabular}{lllcc}
\hline Core number & $\begin{array}{l}\text { Sample } \\
\text { type }\end{array}$ & $\begin{array}{l}\text { CAMS } \\
\text { no. }^{\text {b }}\end{array}$ & $\begin{array}{l}\text { Depth } \\
(\mathrm{cm})\end{array}$ & $\begin{array}{l}\text { Sample age } \\
\left({ }^{14} \mathrm{C} \text { yr B.P. } \pm 1 \sigma\right)\end{array}$ \\
\hline MLB003D & TOC & 72362 & $1-5$ & $610 \pm 70$ \\
MLC001T & TOC & 70933 & $23-27$ & $1860 \pm 40$ \\
MLC001T & Pollen & 70937 & $23-27$ & $340 \pm 70$ \\
MLC001 & TOC & 72364 & $74-78$ & $610 \pm 70$ \\
MLC001 & TOC & 70934 & $120-124$ & $5400 \pm 50$ \\
MLC001 & Pollen & 70938 & $120-124$ & $1510 \pm 70$ \\
MLC001 & TOC & 72365 & $152-156^{\mathrm{c}}$ & $22,270 \pm 1010$ \\
MLC001 & TOC & 70935 & $343-347$ & $31,140 \pm 460$ \\
MLC001 & Pollen & 70939 & $343-347$ & $18,800 \pm 680$ \\
MLC001 & TOC & 72366 & $428-432$ & $22,780 \pm 780$ \\
MLC002 & TOC & 70936 & $649-653$ & $24,650 \pm 200$ \\
MLC002 & Pollen & 70940 & $649-653$ & $18,170 \pm 440$ \\
MLC002 & TOC & 72361 & $765-769$ & $19,700 \pm 590$
\end{tabular}

\footnotetext{
${ }^{a}$ TOC, total organic carbon fraction.

${ }^{\mathrm{b}}$ CAMS, samples analyzed by Center for Accelerator Mass Spectrometry (CAMS) facility at Lawrence Livermore National Laboratory.

${ }^{\mathrm{c}}$ Sample from basal $4 \mathrm{~cm}$ of laminated unit. The age of this sample probably reflects the incorporation of Pleistocene age TOC in sediments that were deposited after the Paoha slump.

${ }^{\mathrm{d}}$ About 12,000 grains of pine pollen were picked for each ${ }^{14} \mathrm{C}$ analysis.
} 


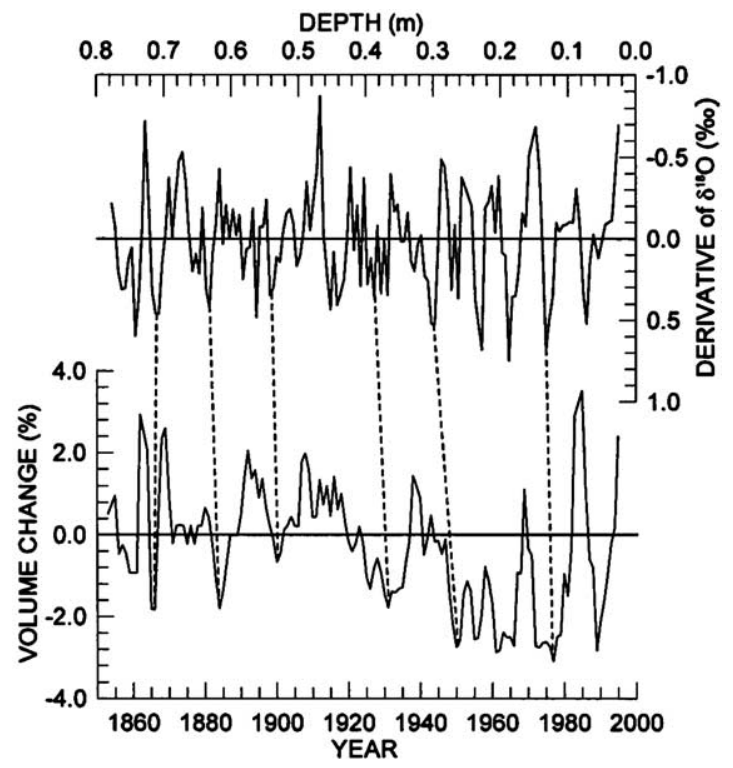

Fig. 4. Comparison of the annual change in volume (\%) of Mono Lake between A.D. 1850 and 1995 (Stine, 1987) with the derivative of $\delta^{18} \mathrm{O}$ with respect to depth (every $0.5 \mathrm{~cm}$ ) in core MLB003D. Dashed lines indicate suggested tie points between the two records.

age (Table 1). The discontinuity in ages above and below $152 \mathrm{~cm}$, and the disorder of ages below $156 \mathrm{~cm}$ are consistent with the hypothesis that the deeper sediments are part of a slump that occurred during the emergence of Paoha Island. The late-Pleistocene age of the $152-$ to $156-\mathrm{cm}$ interval is interpreted to indicate that old carbon released to the lake from slumped Pleistocene sediments was incorporated in laminated sediments deposited after the slump.

Two Mono Craters tephras which date at $\sim 600$ (Sieh and Bursick, 1986) and $\sim 1190$ (Wood, 1977) ${ }^{14} \mathrm{C}$ yr B.P. had been noted previously in shallow-water cores taken from Mono Lake by Newton (1994) and in cuts and pits throughout the Mono Lake basin (Stine, 1990), but were not encountered in this study. The absence of these tephras and the nearly invariant low concentration of TIC below the laminated unit $(0.5 \pm 0.1 \% \mathrm{C}$, Fig. 3) support the concept that sediments below $156 \mathrm{~cm}$ are not late Holocene but rather Pleistocene in age. The TIC values are consistent with TIC values of Tioga-age glacier sediments from the Wilson Creek Formation (see Fig. 5 in Benson et al., 1998).

The ${ }^{14} \mathrm{C}$ ages of the TOC and pollen fractions (Table 1) from above $156 \mathrm{~cm}$ were rejected because sedimentation rates based on either data set are much smaller (6 to 46 times) than that documented by Jellison (1996). This suggests that some of the pollen fraction was reworked from older sediments bordering the lake. The elevated TOC ages are probably attributable to both reworking and a variable reservoir effect. Oremland et al. (1987) have shown that numerous seeps and springs within the Mono Lake basin contribute "old" methane and carbon dioxide to Mono Lake bottom water with some of the seep gases having $>20,000$ ${ }^{14} \mathrm{C}$ yr ages.

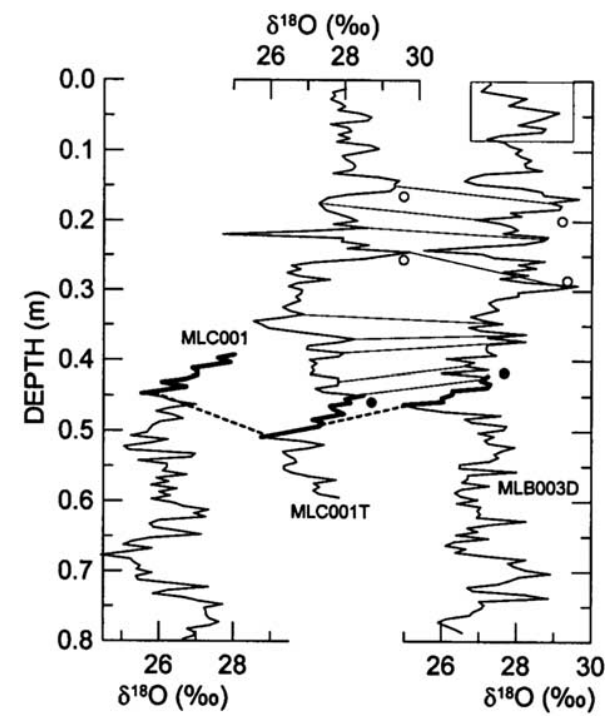

Fig. 5. Correlation of $\delta^{18} \mathrm{O}$ records from cores MLC001, MLC001T, and MLB003D. Open circles indicate locations of thin white layers that contained volcanic tephra. Solid circles indicate locations of similar magnetic susceptibility feature in cores MLC001T and MLB003D. Thin black lines indicate points of correlation between $\delta^{18} \mathrm{O}$ records. Thick lines overlying the three $\delta^{18} \mathrm{O}$ records indicate a corresponding trend in $\delta^{18} \mathrm{O}$ which began in A.D. 1914

Use of $\delta^{18} \mathrm{O}$ and lake volume records to construct an age model

Given the unreliability of the ${ }^{14} \mathrm{C}$ data, the MLB003D $\delta^{18} \mathrm{O}$ record was linked to the historical Mono Lake volume record (A.D. 1850 to 2000) to produce an age model for this interval. A comparison of the annual change in volume of Mono Lake with the derivative of $\delta^{18} \mathrm{O}$ with respect to depth in core MLB003D allowed correlation of the two records of lake-size change between A.D. 1865 and 2000 (Fig. 4). Sedimentation rates for six intervals in core MLB00D were obtained (Table 2).

To obtain an age model for the lower part of the laminated interval in core MLC001, $\delta^{18} \mathrm{O}$ features in the upper part of core MLC001 were matched with $\delta^{18} \mathrm{O}$ features in the MLB003D record and the MLC001T record (Fig. 5). The position of A.D. 1914 in core MLB003D was assigned to the 44-cm depth in core MLC001 and a mean sedimentation rate of $0.512 \mathrm{~cm} \mathrm{yr}^{-1}$ was calculated for the 0 - to

Table 2

Sedimentation rates for six intervals in core MLB003D

\begin{tabular}{lcl}
\hline Time interval $(\mathrm{yr})$ & Depth interval $(\mathrm{cm})$ & Sedimentation rate $\left(\mathrm{cm} \mathrm{yr}^{-1}\right)$ \\
\hline $1865-1884$ & $63-71$ & 0.421 \\
$1884-1900$ & $54-63$ & 0.562 \\
$1900-1931$ & $39-54$ & 0.484 \\
$1931-1950$ & $30-39$ & 0.474 \\
$1950-1977$ & $13.5-30$ & 0.611 \\
$1977-2000$ & $0-13.5$ & 0.587
\end{tabular}


44-cm interval and used to extrapolate ages of samples from 44 to $156 \mathrm{~cm}$, resulting in a A.D. 1700 date for the base of the laminated unit. Given the fact that some compaction may have occurred in the deeper parts of the laminated unit, the A.D. 1700 date may slightly underestimate the age of Paoha Island.

\section{Results}

The age of the base of the laminated unit indicates that the submarine slump that accompanied uplift and doming of the Mono Lake basin floor probably occurred shortly before A.D. 1700. During emergence of Paoha Island, Pleistoceneage sediments were shed from the sides of emerging dome, forming a deposit that caps late-Holocene sediments in deep-water areas surrounding the island. The A.D. 1700 date is supported by observations of Stine (1987), who argued, using geomorphic evidence, that emergence occurred between A.D. 1687 and 1783 .

\section{Limits on the reliability of the Mono Lake $\delta^{18} \mathrm{O}$ record}

On annual and multiannual scales, the $\delta^{18} \mathrm{O}$ record for Mono Lake fails to mimic the historic volume record; that is, negative excursions in $\delta^{18} \mathrm{O}$ values do not always correlate with increases in lake volume and the $\delta^{18} \mathrm{O}$ record is much "noisier" than the volume record (Fig. 6). In order to determine what the Mono Lake $\delta^{18} \mathrm{O}$ record should look like in the absence of meromixis (chemical stratification), temperature differences during carbonate precipitation, and reworking and transport of the carbonate fraction, we used the hydrologic-isotopic-balance model (HIBAL; Benson and Paillet, 2002) to simulate the $\delta^{18} \mathrm{O}$ record between A.D. 1850 and 1995 (dashed line in Fig. 6). The simulated $\delta^{18} \mathrm{O}$ record tends to mirror the volume record, except that increases in wetness are exaggerated in the $\delta^{18} \mathrm{O}$ record when lake volumes are small (e.g., the simulated 3\% negative shift in $\delta^{18} \mathrm{O}$ that accompanied the A.D. 1981 to 1986 increase in lake volume).

Several phenomena may be responsible for observed differences between the actual and simulated $\delta^{18} \mathrm{O}$ records, including (1) errors in the age model, (2) incomplete mixing of the lake's mixed layer, (3) meromixis, (4) variation in the temperature of carbonate precipitation, (5) variation in the form of carbonate precipitate, and (6) reworking and transport of detrital carbonate to deep-water sites.

The HIBAL model simulates instantaneous and complete mixing within a lake's epilimnion and precipitation of a single carbonate phase at the same time each year. This simulation only approximates reality. Mixing does not occur instantaneously within the epilimnion volume. Carbonate precipitation tends to occur within the upper surface of the epilimnion, where temperatures are elevated and where buoyant isotopically light input water may tend to temporarily "float" on denser lake water. Under these conditions,

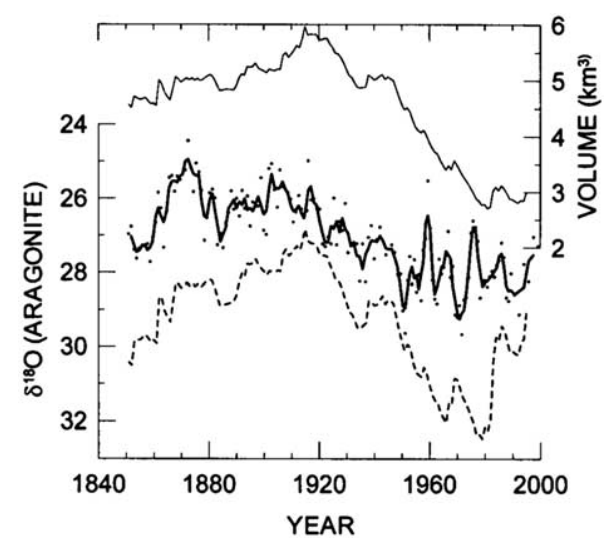

Fig. 6. Comparison of Mono Lake historical volume (upper solid line) with simulated $\delta^{18} \mathrm{O}$ record (lower dashed line) and with smoothed (3-yr running average) measured $\delta^{18} \mathrm{O}$ record (center thick line). To determine how the Mono Lake $\delta^{18} \mathrm{O}$ historical record would look under ideal conditions, the HIBAL model was used to simulate the record between A.D. 1850 to 1995 (Benson and Paillet, 2002). Estimates of fluid input to Mono Lake are available only for A.D. 1937 to 1983 . We, therefore, calculated annual (water year) changes in lake volume between A.D. 1850 and 1995 using measured and estimated lake levels together with hypsometric data from Vorster (1985). A constant evaporation rate of $1.2 \mathrm{~m} \mathrm{yr}^{-1}$ was then used together with calculated annual changes in lake volume and surface area to estimate total input (inflow plus on-lake precipitation) to the lake. Our calculated mean-annual input between A.D. 1937 and 1983 was 4\% greater than that estimated by Vorster (1985). The initial $\delta^{18} \mathrm{O}$ value of lake water was set to $0.0 \%$ and the $\delta^{18} \mathrm{O}$ value of fluid input was set to $-15 \%$. The initial lake depth was set to its A.D. 1850 value (54.26 m; Stine, 1987). Monthly values of air temperature, surface-water temperature, depth of mixed layer, relative humidity, and wind speed used by HIBAL to calculate the evaporation and carbonate-water fractionation factors were obtained from the University of California at Santa Barbara (Jellison, R., personal communication, 2002). Surface temperatures are A.D. 1995 to 2001 monthly averages from 0 to $2 \mathrm{~m}$; air temperatures are monthly averages of 10-min data from A.D. 1990-2001. Humidity data are monthly averages of 10-min data from A.D. 1991 to 2001, and thermocline data are from A.D. 1997 to 2001. Precipitation of carbonate (aragonite) was caused to occur in the eighth month (August) when the water temperature was $20.7^{\circ} \mathrm{C}$.

the $\delta^{18} \mathrm{O}$ value of the carbonate precipitate will be more negative than if it had formed within a well-mixed epilimnion.

An extreme example of incomplete mixing occurs when a lake becomes chemically stratified. Mono Lake salinities increased to $\sim 98 \mathrm{~g} \mathrm{~L}^{-1}$ by A.D. 1980 , and since then, because of its hypersalinity, the lake has exhibited a tendency to chemically stratify during wet years (e.g., between A.D. 1982 and 1988; Jellison and Melack, 1993). Under these conditions, the $\delta^{18} \mathrm{O}$ value of the periodically mixed layer (the mixolimnion) may bear little relation to the mean $\delta^{18} \mathrm{O}$ value of the lake, and carbonate precipitated from the mixolimnion may experience large excursions in $\delta^{18} \mathrm{O}$.

In the HIBAL model, carbonate precipitation is prescribed to occur during August, when the temperature of the epilimnion reaches a maximum $\left(20.7^{\circ} \mathrm{C}\right)$. Temperature exerts a strong influence on carbonate precipitation in that 


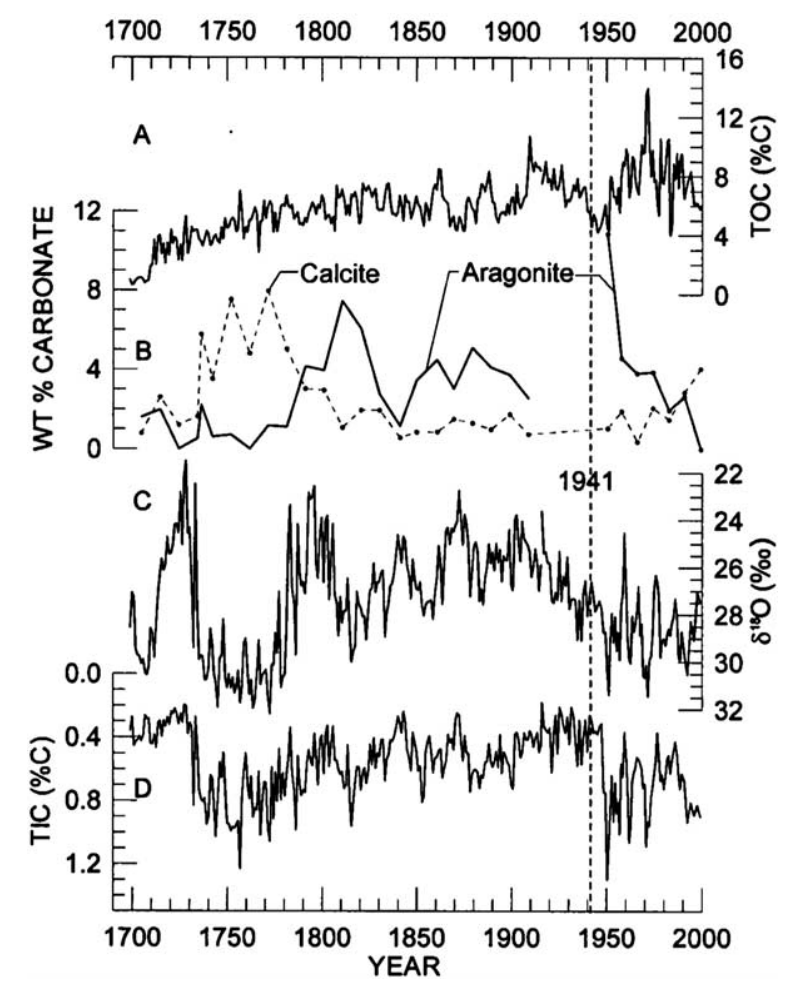

Fig. 7. Mono Lake TOC (A), carbonate (B), $\delta^{18} \mathrm{O}(\mathrm{C})$, and TIC (D) records for the period A.D. 1700 to 1995 . Aragonite is denoted by the solid line and calcite is denoted by the dashed line in (B). Note the correspondence between peaks and troughs in the $\delta^{18} \mathrm{O}$ and TIC records. Dashed vertical line marks the beginning (A.D. 1941) of exportation of water from the Mono Lake basin to Southern California.

aragonite and calcite solubilities decrease with increasing temperature; that is, equilibrium constants $\left(K_{\mathrm{EQ}}\right)$ for aragonite and calcite decrease with increasing temperature. However, the ion activity product (IAP) of these minerals is not constant over time and the saturation state $\left(\mathrm{IAP} / K_{\mathrm{EQ}}\right)$ of these minerals may achieve an optimum value at a different time of year. For example, if carbonate is precipitated in June, when water temperatures average $16.7^{\circ} \mathrm{C}$, the $\delta^{18} \mathrm{O}$ value of the carbonate would be $\sim 0.84 \%$ larger than if it had precipitated in August.

Aragonite or calcite can dominate the carbonate fraction of Mono Lake sediments (Fig. 7B). The $\delta^{18} \mathrm{O}$ fractionation factor $(\alpha)$ for these minerals is not the same; that is, the $\delta^{18} \mathrm{O}$ value of aragonite is $\sim 0.6 \%$ larger than that of calcite formed at $25^{\circ} \mathrm{C}$ (Tarutani et al., 1969).

Reworking and transport of detrital carbonate to deepwater sites probably occurs to some extent at all times, but the magnitude of this process tends to increase when lake volumes are small and transport distances to deep-water sites are minimized (Benson et al., 2002). The greatest differences between simulated and measured $\delta^{18} \mathrm{O}$ records for Mono Lake occur after A.D. 1950, when lake volume had been severely reduced by surface-water diversion (Fig. 6). Some of the negative $\delta^{18} \mathrm{O}$ excursions documented in the sediment record after A.D. 1950 probably resulted from reworking and transport of isotopically light detrital carbonate to the MLB003 core site. In addition, low lake levels that accompanied the 45-yr drought that began in A.D. 1735 may have been responsible for substantial reworking of older pollen into the eastern basin of the lake. This would account for the $1510 \pm 70{ }^{14} \mathrm{C}$ yr B.P. date (CAMS 70938, Table 1) of the pollen fraction from the 120- to 124-cm level (A.D. 1762 to 1770 ) of core MLC001.

The phenomena discussed above alter the lake-water $\delta^{18} \mathrm{O}$ record contained within the carbonate fraction. In the case of Mono Lake, this implies that TIC $\delta^{18} \mathrm{O}$ records at annual and multiannual time- scales are not always representative of the $\delta^{18} \mathrm{O}$ values of lake water. Variability over longer time intervals (decades to centuries) is, however, generally representative of the $\delta^{18} \mathrm{O}$ evolution of lake water as evidenced by the shapes and amplitudes of decadal- and century-scale fluctuations observed in the simulated and measured $\delta^{18} \mathrm{O}$ records (Fig. 6).

\section{Sierra Nevada records of climate change}

The $\delta^{18} \mathrm{O}$ value of a carbonate precipitated from a closed-basin lake is a function of several climate-related variables, including air temperature, water temperature, relative humidity, and windspeed (Benson et al., 2002). However, the excellent correspondence between decadal and multidecadal trends in Mono Lake TIC and $\delta^{18} \mathrm{O}$ records (Figs. 7C and 7D) indicates that the Mono Lake $\delta^{18} \mathrm{O}$ record principally reflect changes in hydrologic balance (Benson et al., 2002). Negative excursions in $\delta^{18} \mathrm{O}$ reflect times when fluid inputs exceed fluid output via evaporation and vice versa.

During the past 100 years, Mono Lake was usually monomictic; that is, it mixed fully in November after it achieved thermal homogeneity. In the Great Basin, it is believed that the bulk of $\mathrm{CaCO}_{3}$ precipitation occurs when the mixed layer (epilimnion) achieves its highest temperatures (e.g., Galat and Jacobsen, 1985). The $\delta^{18} \mathrm{O}$ value of the mixed layer at the time of precipitation (usually August or September) is a function of the volume-weighted $\delta^{18} \mathrm{O}$ value of water derived from the fully mixed lake during the previous November plus the volume-weighted $\delta^{18} \mathrm{O}$ value of water input to the lake minus the volume-weighted $\delta^{18} \mathrm{O}$ value of water lost to evaporation. In addition, the $\delta^{18} \mathrm{O}$ value of a carbonate precipitate is a function of water temperature, decreasing $\sim 0.21 \%$ for every $1^{\circ} \mathrm{C}$ decrease in temperature (O'Neil et al., 1969).

The $\delta^{18} \mathrm{O}$ record prior to A.D. 1941 indicates relatively dry periods centered on A.D. 1710, 1770, 1820?, 1850, and 1930 (Fig. 7C). Rather remarkable changes in the TOC, $\delta^{18} \mathrm{O}$, and TIC records occur about a decade after diversion of water from the Mono Lake basin commenced (A.D. 1941), with increases in the levels of all three parameters reflecting the loss of natural inputs. The existence of the low lake level at $\sim 1855$ A.D. was previously documented by Harding (1965), using early estimations and measurements 
of the levels of several Great Basin lakes, including Goose Lake, Oregon; Pyramid Lake, Nevada; Winnemucca Lake, Nevada; Walker Lake, Nevada; and Mono Lake, California. The 45-yr drought period (A.D. 1735 to 1780) characterized by elevated $\delta^{18} \mathrm{O}$ values (Fig. 7C) was also characterized by calcite precipitation (Fig. 7B).

The Mono Lake $\delta^{18} \mathrm{O}$ data were smoothed by taking a 15 -yr running average that emphasized the interdecadal peaks and troughs visible in the raw data set. The smoothed Mono Lake $\delta^{18} \mathrm{O}$ record (Fig. 8A) was then compared with tree-ring-based reconstructions of southern Sierran precipitation (Graumlich, 1993) (Fig. 8B) and northern Sierran discharge (Meko et al., 2001) (Fig. 8D). A 15-yr running average of the $\delta^{18} \mathrm{O}$ record indicates that five isotopically depleted intervals (wet periods) occurred prior to the A.D.

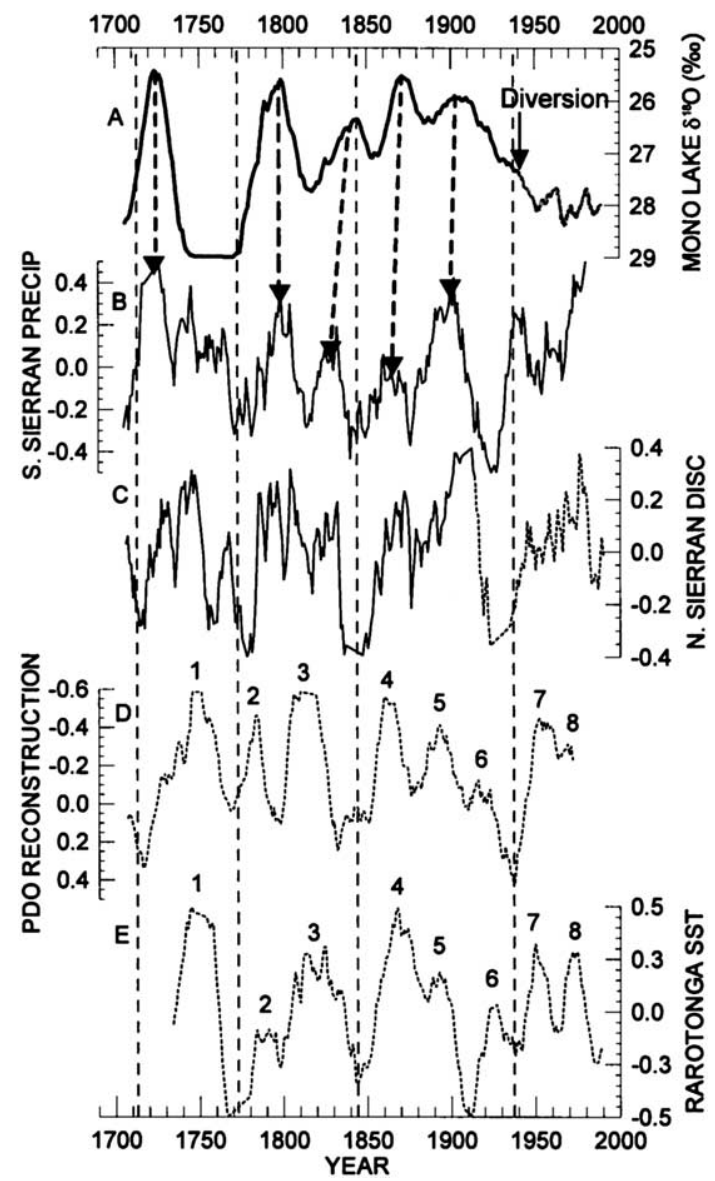

Fig. 8. Comparison of smoothed (15-yr running average) records of (A) Mono Lake $\delta^{18} \mathrm{O}$ record, (B) Southern Sierran precipitation (Graumlich, 1993), (C) Northern Sierran discharge (Meko et al., 2001), (D) PDO index (D'Arrigo et al., 2000), and (E) detrended Subtropical South Pacific SST (Linsley et al., 2000). Detrending was done using a second-degree polynomial. All data sets except the $\delta^{18} \mathrm{O}$ record were normalized by subtracting the mean from each value and dividing by the standard deviation. Arrows connect volume maxima of Mono Lake with precipitation maxima in the southern Sierra Nevada. The gray line in (A) indicates Mono Lake $\delta^{18} \mathrm{O}$ values after diversion of water out of the Mono Lake basin. Numbers refer to PDO minima and central South Pacific gyre SST maxima. Thin vertical dashed lines connect PDO maxima with Sierran precipitation minima and depressed Subtropical South Pacific SST.
1941 diversion of water from the Mono Lake basin (Fig. $8 \mathrm{~A})$. The oldest four wet periods were not noted in the discontinuous lake-level record produced by Stine (1990). Because of the diversion, $\delta^{18} \mathrm{O}$ variations after A.D. 1941 are not expected to correspond closely to changes in Sierran wetness because changes in Mono Lake volume were no longer closely tied to changes precipitation in the Mono Lake basin.

On multidecadal time scales there is a generally good correspondence between the $\delta^{18} \mathrm{O}$ record and the tree-ring records; that is, the wet periods in the $\delta^{18} \mathrm{O}$ record correlate reasonably well with the tree-ring-based wet periods (Figs. $8 \mathrm{~A}, 8 \mathrm{~B}$, and $8 \mathrm{C})$. However, the oldest wet period centered on A.D. 1725 in the $\delta^{18} \mathrm{O}$ record does not persist as long as the wet periods evidenced in the two tree-ring records. In addition, the wet period in the $\delta^{18} \mathrm{O}$ record that culminates $\sim$ A.D. 1845 lags the tree-ring-based wet period that culminates $\sim$ A.D. 1832 . This may have more to do with inaccuracies inherent in our age model than with problems in the $\delta^{18} \mathrm{O}$ proxy of change in hydrologic balance. The extreme drought evidenced by a trough in $\delta^{18} \mathrm{O}$ values between A.D. 1740 and 1780 (Fig. 8A) does not appear as a single event in the tree-ring reconstructions (Figs. 8B and 8C). This may indicate that the Mono Lake basin experienced a greater reduction in precipitation during this period than regions located north or south of it. Differences in the decadal-scale features of the two tree-ring records (Figs. 8B and 8C) probably reflect variability in precipitation between the southern and northern Sierra Nevada.

Comparison of Sierra Nevada records of climate change with reconstructions of the PDO index and subtropical south pacific sea-surface temperatures (SST)

To evaluate the regional significance of the three Sierran records of wetness (Figs. 8A, 8B, and 8D) we compared them with a tree-ring-based reconstruction of the PDO index (Fig. 8C)(D'Arrigo et al., 2001) and a coral-based reconstruction of Subtropical South Pacific SST (Fig. $8 \mathrm{E})$ (Linsley et al., 2000). The latter study had previously demonstrated that the reconstructed South Pacific SST record could be correlated with the instrumental-based PDO index (Mantua et al., 1997) for the past $97 \mathrm{yr}$.

Positive values of the PDO index indicate elevated SST along the coast of western North America, low sea-level pressure (SLP) over the North Pacific, and high SLP over the western United States (Mantua et al., 1997). A positive (warm) PDO is thought to have a similar spatial precipitation signature as an El Niño event (wet in the American Southwest and dry in the Pacific Northwest), and a negative (cool) PDO has a similar signature as a La Niña event. However, as Mantua and Hare (2002) have noted: "the climatic fingerprints of the PDO were most visible in the extratropics, especially in the North Pacific/North America sector." PDO regimes persisted for 20 to $30 \mathrm{yr}$, whereas El Niño-Southern Oscillation 
(ENSO) events persisted for 6 to 18 months in the 20th century. Redmond and Koch (1991) have previously shown that, for the period 1931 to 1984, October-March precipitation in the northern Sierra Nevada (between $38^{\circ}$ and $41^{\circ} \mathrm{N}$ ) was not correlatable to ENSO events. McCabe and Dettinger (1999) supported the findings of Redmond and Koch (1991) and also showed that ENSO teleconnections with precipitation in the western United States are influenced by the strengths of the June-November Southern Oscillation Index (SOI), the PDO, and the average of SST anomalies over the region encompassed by $90^{\circ}$ to $150^{\circ} \mathrm{W}$ longitude and $5^{\circ} \mathrm{N}$ to $5^{\circ} \mathrm{S}$ latitude.

A link between the climate of the Sierra Nevada and the PDO has previously been reported. Cayan (1996) has shown that the leading eigenvector of snowpack variability in the western United States (the Idaho pattern) is centered in the Pacific Northwest. Mantua et al. (1997) showed that the Idaho pattern has tracked their PDO index since at least A.D. 1935. The pattern of snowpack variability (wetness) was found to be consistent with relative warm winter temperatures and anomalously low winter precipitation occurring throughout the Pacific Northwest as far south as $38^{\circ} \mathrm{N}$ during positive PDO years (Fig. 3 of Mantua et al., 1997). That is, historically the region effected during positive PDO phases reached as far south as the Mono Lake basin. However, the extent to which the PDO has consistently influenced the hydrologic balance of the Mono Lake basin has yet to be determined.

We have elected to use the PDO reconstruction of D'Arrigo et al. (2001) rather than the reconstructions of Gedalof and Smith (2001) and Biondi et al. (2001). D'Arrigo et al. (2001) incorporated tree-ring records from both temperature-sensitive sites in coastal Alaska and the Pacific Northwest and from precipitation-sensitive sites in subtropical western Mexico, demonstrating stronger calibration and verification results than other studies. Both Mantua et al. (1997) and Salinger et al. (2001) have demonstrated that the PDO is a pan-Pacific phenomena, and we believe that tree-ring-based reconstructions of the PDO index that incorporate sites from a wide range of latitudes are preferred over those confined to single geographic areas.

The Subtropical South Pacific SST and reconstructed, detrended PDO records are phase locked, with eight maxima in SST occurring at the same time as eight minima in the PDO index (Figs. 8D and 8E). The relative amplitudes of seven of eight oscillations are the same in both records. In addition, exceptionally dry periods in the records of Sierran wetness (Figs. 8B and 8C) tend to occur during maxima in the PDO index (thin dashed lines in Fig. 8). An exception to this rule is the 1930s drought that preceded a PDO maximum by about 2 decades. In general, the correlation of extreme dry periods in the Sierra Nevada with positive phases of the PDO index is found to be consistent with the results of Cayan (1996) and Mantua et al. (1997), but extends this record back 300 years.

\section{Summary and conclusions}

Since the emergence of Paoha Island $\sim$ A.D. 1700, central Sierran Mono Lake laminated sediments have recorded an accurate decadal-scale history of lake-size variability. The smoothed $\delta^{18} \mathrm{O}$ record in Mono Lake sediments indicates the existence of five oscillations in the hydrologic balance between A.D. 1700 and 1941. These oscillations can be correlated with tree-ring-based records of wetness from the northern and southern Sierra Nevada.

Comparison of a robust tree-ring-based reconstruction of the PDO index (D'Arrigo et al., 2001) with a coral-based reconstruction of Subtropical South Pacific SST (Linsley et al., 2000) indicates a high degree of correlation of the two records during the past $300 \mathrm{yr}$, confirming that the PDO is a pan-Pacific phenomenon.

Major negative perturbations in the hydrologic balance of the Sierra Nevada occur during PDO maxima. Four droughts centered on A.D. 1710, 1770, 1850, and 1930 indicate PDO-related drought reoccurrence intervals ranging from 60 to $80 \mathrm{yr}$. This range of periodicity is consistent with the findings of several authors. Mann et al. (1995) employed a frequency-domain singular value decomposition method to a set of temperature proxy reconstructions for the past $500 \mathrm{yr}$. They found that before $1650 \mathrm{AD}$ a coherent signal with a 50-yr period appeared intermittently, but after $1650 \mathrm{AD}$, the oscillation strengthened and drifted to a 60- to 70-yr periodicity. Minobe (1997) showed that the leading EOF of the tree-ring-based temperature reconstructions of Fritts (1991) has a peak periodicity of 50 to $70 \mathrm{yr}$. Minobe $(1999,2000)$ also applied wavelet analysis to North Pacific SST and SLP records, finding that PDO fluctuations were most energetic in the 15- to 25-yr and 50- to 70-yr bands. And Chao et al. (2000) applied Singular Spectrum Analysis to a persistence index of North Pacific SST, finding oscillatory behavior in the $15-$ to $20-\mathrm{yr}$ and $\sim 70-\mathrm{yr}$ bands.

With a greater understanding of the climate processes that control the evolution of the PDO, it may prove possible to predict the occurrence of some of the extreme droughts that impact the Sierra Nevada and the regions to which it drains (Fig. 1). Whereas tree-ring-based reconstructions of change in the hydrologic balance are preferable in terms of age control, lake-based reconstructions offer a means of determining the nature of climate change over much greater periods of time (several millennia).

\section{Acknowledgments}

Conversations with Marcus Bursik and Robert Jellison were helpful in understanding the emergence of Paoha Island and the mixing behavior of Mono Lake. Robert Jellison also provided us input data for the HIBAL simulations. Fred Paillet altered the HIBAL model for application to Mono Lake. We thank Larry Ford for permitting our coring of 
Mono Lake. Alan Heyvaert and Bob Richards took the box cores, and Stephen Howe at the University at AlbanySUNY performed the $\delta^{18} \mathrm{O}$ analyses. Dennis Eberl assisted with the X-ray diffraction study and Andrew Taylor was responsible for sample preparation and coulometric analysis. Dave Meko, Rosanne D'Arrigo, and Lisa Graumlich allowed us to access their tree-ring-based reconstructions. This work was partially supported by the U.S. Geological Survey Earth-Surface Dynamics program.

\section{References}

Benson, L.V., Burdett, J.W., Kashgarian, M., Lund, S.P., Phillips, F.M., Rye, R.O., 1996. Climatic and hydrologic oscillations in the Owens Lake basin and adjacent Sierra Nevada, California. Science 274, 746749.

Benson, L.V., Kashgarian, M., Rye, R.O., Lund, S.P., Paillet, F.L., Smoot, J., Kester, C., Mensing, S., Meko, D., Lindstrom, S., 2002. Holocene multidecadal and multicentennial droughts affecting northern California and Nevada. Quaternary Science Reviews 21, 659-682.

Benson, L.V., Lund, S.P., Burdett, J.W., Kashgarian, M., Rose, T.P., Smoot, J., Schwartz, M.D., 1998. Correlation of late-Pleistocene lakelevel oscillations in Mono Lake, California, with North Atlantic climate events. Quaternary Research 49, 1-10.

Benson, L.V., Paillet, F.L., 2002. HIBAL: a hydrologic-isotopic-balance model for application to paleolake systems. Quaternary Science Reviews, 21, 1521-1539.

Biondi, F., Gershunov, A., Cayan, D.R., 2001. North Pacific decadal climate variability since 1661 . Journal of Climate $14,5-10$.

Cayan, D.R., 1996. Interannual climate variability and snowpack in the western United States. Journal of Climate 9, 928-948.

Chao, Y., Ghil, M., McWilliams, J.C., 2000. Pacific interdecadal variability in this century's sea surface temperatures. Geophysical Review Letters 27, 2261-2264.

D'Arrigo, Villalba, R., Wiles, G., 2001. Tree-ring estimates of Pacific decadal climate variability. Climate Dynamics 18, 219-224.

Davis, O.K., 1999. Pollen Analysis of a late-glacial and Holocene sediment core from Mono Lake, Mono County, California. Quaternary Research $52,243-249$.

Fritts, H.C., 1991. "Reconstructing Large-Scale Climatic Patterns from Tree-Ring Data." University of Arizona Press, Tucson.

Galat, D.L., Jacobsen, R.L., 1985. Recurrent aragonite precipitation in saline-alkaline Pyramid Lake, Nevada. Archiv fur Hydrobiologie 105, $137-159$

Gedalof, Z., Smith, D.J., 2001. Interdecadal climate variability and regimescale shifts in Pacific North America. Geophysical Research Letters 28, $1515-1518$.

Graumlichf, L.J., 1993. A 1000-year record of temperature and precipitation in the Sierra Nevada. Quaternary Research 39, 249-255.

Harding, S.T. (1965). Recent variations in the water supply of the western Great Basin, in: "Water Resources Center Archives Series Report No. 16", University of California, pp. 226.

Jellison, R., 1996. Organic matter accumulation in sediments of hypersaline Mono Lake during a period of changing salinity. Limnology, Oceanography 41, 1539-1544.

Jellison, R., Melack, J.M., 1993. Meromixis in hypersaline Mono Lake, California. 1. Stratification and vertical mixing during the onset, persistence, and breakdown of meromixis. Limnology, Oceanography 38 , $1008-1019$.

Li, H., Ku, T., Stott, L.D., Anderson, R.F., 1997. Stable isotope studies on Mono Lake (California). 1. $\delta^{18} \mathrm{O}$ in lake sediments as proxy for climatic change during the last 150 years. Limnology, Oceanography 42, 230 238.
Linsley, B.K., Wellington, G.M., Schrag, D.P., 2000. Decadal sea surface temperature variability in the Subtropical South Pacific from 1726 to 1997 A.D. Science 290, 1145-1148.

Mann, M.E., Park, J., Bradley, R.S., 1995. Global interdecadal and centuryscale climate oscillations during the past five centuries. Nature 378, $266-270$.

Mantua, N.J., Hare, S.R., Zhang, Y., Wallace, J.M., Francis, R.C., 1997. A Pacific interdecadal climate oscillation with impacts on salmon production. Bulletin of American Meteorological Society 78, 1069-1079.

Mantua, N.J., Hare, S.R., 2002. The Pacific Decadal Oscillation. Journal of Oceanography 58, 35-44.

McCabe, G.J., Dettinger, M.D., 1999. Decadal variations in the strength of ENSO teleconnections with precipitation in the western United States. International Journal of Climatology 19, 1399-1410.

Meko, D.M., Therrell, M.D., Baisan, C.H., Hughes, M.K., 2001. Sacramento River flow reconstructed to A.D. 869 from tree rings. Journal American Water Resources Association 37, 1029-1040.

Minobe, S., 1997. A 50-70 year climatic oscillation over the North Pacific and North America. Geophysical Review Letters 24, 683-686.

Minobe, S., 1999. Resonance in bidecadal and pentadecadal climate oscillations over the North Pacific: role in climatic regime shifts. Geophysical Review Letters 26, 855-858.

Minobe, S., 2000. Spatio-temporal structure of the pentadecadal variability over the North Pacific. Progress in Oceanography 47, 381-408.

Newton, M., 1994. Holocene fluctuations of Mono Lake, California: the sedimentary record. Society for Economic Paleontologists and Mineralogists, Society for Sedimentary Geology Special Publication 50, 143-157.

O'Neil, J.R., Clayton, R.N., Mayeda, T.K., 1969. Oxygen isotope fractionation in divalent metal carbonates. Journal of Chemical Physics 50, $5547-5558$.

Oremland, R.S., Miller, L.G., Whiticar, M.J., 1987. Sources and fluxes of natural gases from Mono Lake, California. Geochimica et Cosmochimica Acta 51, 2915-2929.

Redmond, K.T., Koch, R.W., 1991. Surface climate and streamflow variability in the western United States and their relationship to large-scale circulation indices. Water Resources Research 27, 2381-2399.

Russell, I.C., 1889. Quaternary History of the Mono Valley, in: "Eighth Annual Report of the U.S. Geological Survey”, California, pp. 267394.

Salinger, M.J., Renwick, J.A., Mullan, A.B., 2001. Interdecadal Pacific Oscillation and South Pacific Climate. International Journal of Climate 21, 105-1721.

Sieh, K., Bursik, M., 1986. Most recent eruption of the Mono Craters, eastern central California. Journal of Geophysical Research 91, 12539_ 12571.

Stine, S., 1987. "Mono Lake: The Past 4000 Years". Unpublished Ph.D. thesis, University of California, Berkeley.

Stine, S., 1990. Late Holocene fluctuations of Mono Lake, eastern California. Palaeogeography, Palaeoclimatology, Palaeoecology 78, 333381.

Stuiver, M., Reimer, P.J., Braziunas, T.F., 1998. High-precision radiocarbon age calibration for terrestrial and marine samples. Radiocarbon 40, $1127-1151$

Tarutani, T., Clayton, R.N., Mayeda, T.K., 1969. The effects of polymorphism and magnesium substitution on oxygen isotope fractionation between calcium carbonate and water. Geochimica Cosmochimica Acta 33, 987-996.

Vorster, P.T., 1985. A water balance forecast model for Mono Lake, California: U.S. Department of Agriculture, Forest Service Region 5. Earth Resources Monograph 10.

Wood, S.H., 1977. Distribution, correlation, and radiocarbon dating of late Holocene tephra, Mono and Inyo craters, eastern California. Geological Society of America Bulletin 88, 89-95. 